\title{
Total War Strategy through Optimizing Pancasila Values
}

\author{
Akhiyar Meideri, Lukman Yudho Prakoso, Helda Risman \\ Prodi Strategi Perang Semesta, Fakultas Strategi Pertahanan, Universitas Pertahanan Indonesia \\ DOI: https://dx.doi.org/10.47772/IJRISS.2021.5413
}

\begin{abstract}
The dynamics of the global regional and national strategic environment have an impact on the emergence of various threats, both actual and potential. The country must prepare for all the possibilities that occur, including preparing for a total war involving all human resources. Pancasila as the Indonesian ideology is one of the most important resources in binding the spirit of the struggle of the Indonesian people in organizing the Total War, so that Pancasila as the state ideology is deemed necessary to always be maintained, maintained and continuously optimized. The purpose of this study was to analyze the "Total War Strategy through Optimizing the Values of Pancasila." The research method used is descriptive qualitative method using secondary data sources in the form of previous research journals, books, documentation, news, internet and others. Based on the results of the study, it can be concluded that the total war strategy includes including all levels of society in state defense activities in accordance with the practice of the 4th precept of Pancasila. Providing information about defending the state, and providing equal treatment to protect and provide security for all Indonesian people in accordance with the 2nd principle. The TNI together with the Government jointly provide protection for the community based on the principles of democracy, human rights and non-discrimination which is in accordance with the value of the 5th principle. Therefore, the values of Pancasila must be maintained and optimized to create a country that is safe and peaceful, a society that lives peacefully and is also prosperous.
\end{abstract}

Keywords: Strategy, War, Universe, Value, Pancasila

\section{INTRODUCTION}

$\mathrm{P}$ ancasila As the basis of the state, ideology, views and philosophy of life that guide life. Pancasila is the foundation of the state which becomes the unifying principle for the Indonesian nation in defending its sovereignty. Pancasila is a strong ideology as a milestone for society to carry out various special life activities when it comes to relationships between humans who have different religions, ethnicities, races and norms. The various noble values that exist in Pancasila are based on the character and culture of the nation that has prevailed throughout the ages (Octavian, 2018)

Along with the changing times and the development of the nation, at this time the things that the founders and the predecessors of the nation had struggled for are undergoing a test phase to maintain them because of the various aspects that can affect, one of which is globalization (AngkasaDipua, 2020). The era of globalization has changed perceptions of threats to the existence of a country. The threats that come are no longer in the form of physical threats, but also in the form of threats that are more complex and reach the dimensions of national and state life. covers all dimensions of national life.

Pancasila is the foundation of the state which becomes the unifying principle for the Indonesian nation in defending its sovereignty. Pancasila is a strong ideology as a milestone for society to carry out various special life activities when it comes to relationships between humans who have different religions, ethnicities, races and norms. (Bhagaskoro, Utungga Pasopati and Syarifuddin, 2019)

The values of Pancasila must be known, understood, and implemented by the Indonesian people in everyday life in order to realize the ideals of the proclamation of independence. However, at this time knowledge, the understanding of the nation's future generations of the values contained in Pancasila, is decreasing and being eroded because of the many new values that are incompatible with the national identity. This problem is of course a threat in itself to the sovereignty of the Indonesian state.

Based on the description on the background, the purpose of this study is to find out how the "Total War Strategy through Optimizing the Values of Pancasila."

\section{METHOD AND THEORY}

The research method is a scientific method that is applied to obtain data and information for specific purposes. The research method in this journal is the literature study method, which is a research method that uses a review of the literature in the form of journals, books, notes, documentation related to the research topic. This type of research approach is descriptive qualitative.

The qualitative descriptive analysis approach is an approach to distinguish, examine, make comparisons, and interpret meaningful patterns or themes. Meaning is determined by the goals and objectives of the research being carried out. The same or different data can be studied or evaluated from different points of view to get answers to the formulation of a particular problem that is being discussed. In qualitative research, researchers can use discourse, textual, narrative, ethnographic approaches in accordance with the objectives and orientation of the study. (John W. Reswell, 2009)

In quantitative analysis, numbers and their meanings are material for analysis. In contrast, qualitative analysis deals 
with words and is guided by fewer Total rules and standard procedures than statistical analysis (Miles, 1994).

The object of research in this journal is the Total war strategy and Pancasila values. While the type of data used in this study is secondary data. Meanwhile, the data analysis techniques used were Miles and Huberman's data analysis techniques, namely data reduction, data display, conclusion drawing and verification.

\section{DISCUSSION}

The research results obtained related to the Total war strategy through the values of Pancasila can be explained as follows:

That the current war has a different form from previous wars involving actors and victims who can be seen with the eye directly. At this time war has various forms that are invisible and victims that cannot be known directly, but the scope of war today is more systematic and also has a very broad impact, for example cyber war, trade war and intelligence war. (Abdi, Wijayanto and Midhio, 2018).

Several studies that apply analysis from the point of view of Total war strategy and indirectly use Pancasila values are as follows:

Research conducted by Abdi, Wijayanto and Midhio (2020) in reducing the DI / TII rebellion explained that the government implemented a form of Total war strategy by including a reserve component from the community around which the rebels lived. Its purpose is to weaken the rebel power. The strategy of Total warfare is also being carried out by inviting the public to work together to defend and protect the sovereignty of the state and the environment in accordance with the 3rd Precept, namely the Unity of Indonesia.

In this case the DII / TII rebellion by the Indonesian military was successfully contained.

Through this strategy, it can be seen that the uniting of the Indonesian people as a reserve and supporting component shows that the community understands and is willing to uphold the values contained in Pancasila(Lukman Ydho Prakoso, 2021a).

The Total war strategy through the application of Pancasila values can also be done by strengthening the sense of nationality of the younger generation. This is motivated by the fact in the field that the Citizenship Education provided to students is still considered insufficient to instill a sense of nationality. In this case the TNI carries out its duties in Military Operations other than War (OMPS), namely by empowering and strengthening the community as an agent of socializing state defense to the community (Nofriadi, Yusuf, 2018).

In carrying out the Total war strategy, the TNI conducts outreach to the public through various media including advertisements on mass media television, electronics and others. In carrying out the socialization, the TNI provides various materials related to state defense (Suhirwan, 2019). The attitude of defending the state is one of the practices of the Pancasila precepts, namely the 3rd principle of the Indonesian Unity.

The obligation to defend the state is the obligation of every person who exists, lives and is the nationality of that country. The attitude of defending the state means being brave and willing to sacrifice for the state and nation with wealth and life for the integrity of the Republic of Indonesia.

In order to empower the community as a reserve component and a supporting component in national defense, the TNI provides information provision for every member of society without exception. (Nofriadi, Yusuf, 2018). This shows that the TNI in this case has implemented the values of Pancasila, especially the 5th principle, namely Social Justice for All Indonesians.

The steps taken by the TNI in improving the attitude of defending the country through the provision of information to all Indonesians through a special website aimed at making all people access without exception.

National defense as a Total or comprehensive war strategy is based on the principles of democracy, human rights, general welfare, social justice for all Indonesian people who are separated in an area consisting of thousands of islands. This reflects the inculcation of the value of Pancasila, namely the second principle, namely Fair and Civilized Humanity. Fair means that security protection must be given to everyone without exception, while being civilized means that security protection is carried out in a manner that does not violate the laws, customs and social norms that apply in Indonesia (AngkasaDipua, 2021).

Pancasila is the state ideology that must be maintained at all times and must be practiced by every Indonesian citizen. Pancasila as an ideology cannot be amended because the principles in Pancasila are directly related to aspects of the life of Indonesian society as a whole, both related to the relationship between humans and God and also the relationship between humans and other humans.

Threats to Indonesia's national security and defense are no longer in the form of conventional threats that are familiar to a country such as colonialism or direct aggression in a country, but today's threats are more difficult to detect or recognize. The complexity of these various threats certainly requires an effective strategy, in this case a Total war strategy.

In the Total war strategy as previously explained, defense in Total war involves all Indonesian people. The Indonesian defense paradigm is embodied in the values of Pancasila which are explained in the preamble of the 1945 Constitution of the Republic of Indonesia and further explained in Law Number 3 of 2002 concerning Defense, namely that the government has a duty to protect all people and the country, promote the general welfare, educate bagsa life and also jointly maintain world order (LukmanYudho Prakoso,2021b). 
Furthermore, Article 30 of the Indonesian Constitution explains that national defense and security efforts are carried out through the defense and security system of the total people by the TNI and Polri as the main component and the people as a reserve component.

In the concept of national defense, the values of Pancasila are the main elements in the national defense system. Pancasila is the foundation of national defense to protect the sovereignty and integrity of the Indonesian state.

\section{CONCLUSION}

The Total war strategy can be done by optimizing the values of Pancasila. Based on the results of the study, it can be concluded that the Total war strategy includes including all levels of society or the Total role of all components of the nation in state defense activities in accordance with the practice of the 4th precept of Pancasila. Providing information about defending the country by the TNI, and providing equal treatment to protect and provide security for all Indonesian people in accordance with the second precept.

The TNI together with the Government jointly provide protection to the community based on the principles of democracy, uphold human rights and non-discrimination in accordance with the value of the 5 th precept.

Thus the suggestion that can be given is that the values of Pancasila are the fundamental values of the Indonesian people that must be maintained and optimized to create a country that is safe and peaceful, a society that lives peacefully and prosperously within the framework of the unitary state of the Republic of Indonesia.

\section{REFERENCES}

[1] Abdi, R. N., Wijayanto, J. and Midhio, I. W. (2018) "ASPEK DIPLOMASI, STRATEGI PERTAHANAN SEMESTA, DAN IRREGULAR WARFARE DALAM PENANGGANAN GERAKAN DISINTEGRASI DI INDONESIA", Strategi Pertahanan Darat, 4(3), pp. 83-102. doi: 10.15408/mimbar.v37i1.17827.

[2] Agus, A. A. (2016) "RELEVANSI PANCASILA SEBAGAI IDEOLOGI TERBUKA DI ERA REFORMASI" A. Aco Agus Fakultas Ilmu Sosial, Universitas Negeri Makassar', Jurnal Office.

[3] Aminullah (2015) "Implementasi Nilai-Nilai Pancasila Dalam
Kehidupan", Jurnal Ilmiah IKIP Mataram.

[4] Anggraini, D. et al. (2020) "Pengamalan Nilai-Nilai Pancasila Bagi Generasi Milenial", Jurnal Inovasi Ilmu Sosial dan Politik. doi: 10.33474/jisop.v2i1.4945.

[5] Bhagaskoro, P., Utungga Pasopati, R. and Syarifuddin, S. (2019) "Pancasila Dalam Interaksi Kearifan Lokal Dan Ideologi Transnasional", Jurnal Inovasi Ilmu Sosial dan Politik. doi: 10.33474/jisop.v1i2.4806.

[6] Dipua, A., Hermawan, R., Puspitawati, D., Harahap, N., Rizanny, D., \& Prakoso, L. Y. (2020). An Analysis of The South China Sea Conflict: Indonesia's Perspectives, Contexts and Recomendations. PalArch's Journal of Archaeology of Egypt/Egyptology, 17(4), 976-990.

[7] Dipua, A., Harahap, N. ., Puspitawati, D. ., Aminuddin, F. ., \& Prakoso, L. Y. (2021). Sea Defense Strategy the Indonesian Navy in Dealing with the South China Sea Conflict. I T A L I E N I S C H, 11(2), 120-126. https://doi.org/10.1115/italienisch.v11i2.103

[8] Honig, J. W. (2011) "The Idea of Total War: From Clausewitz to Ludendorff", Proseeding, (International Volume on War History), pp. 29-41.

[9] Indrawan, R. M. J. and Efriza, E. (2018) "MEMBANGUN KOMPONEN CADANGAN BERBASIS KEMAMPUAN BELA NEGARA SEBAGAI KEKUATAN PERTAHANAN INDONESIA MENGHADAPI ANCAMAN NIR-MILITER", Jurnal Pertahanan \& Bela Negara. doi: 10.33172/jpbh.v8i2.395.

[10] John W.Creswell (2009) "Research design Qualitative, quantitative and mixed method approaches", Intercultural Education.

[11] Latif, Y. (2011) "Negara Paripurna: Historisitas, Rasionalitas dan Aktualitas Pancasila." Jakarta: PT. Gramedia Pustaka Utama.

[12] Miles, M. A. (1994) "Miles and Huberman (1994)- Chapter 4.pdf', in Qualitative Data Analysis": An Expanded Sourcebook.

[13] Nofriadi, Yusuf, H. (2018) "INTERNALISASI NILAI-NILAI BELA NEGARA DENGAN PENDEKATAN BINTER DI WILAYAH KODIM 0618/BSKOTA BANDUNG", Strategi Pertahanan Darat, 4(3), pp. 83-102.

[14] Octavian, W. A. (2018) "Urgensi Memahami dan Mengimplementasikan Nilai-Nilai Pancasila dalam Kehidupan Sehari-Hari Sebagai Sebuah Bangsa", Bhinneka Tunggal Ika.

[15] Prabowo (2019) "Pokok Pokok Pemikiran tentang Perang Semesta." Ke 3. Jakarta: Pusat Pengkajian dan Strategi Nasional.

[16] Prakoso, L. Y. (2021, March 17). Defense Policy Analysis to Deal with Radicalism and Terrorism in Indonesian Universities. https://doi.org/10.31014/aior.1991.04.01.265

[17] Prakoso, L. Y. (2021, March 17). Implementation of Defense Policy Against Threats for Securing International Shipping Lanes in the Sunda Strait. https://doi.org/10.31014/aior.1991.04.01.263

[18] Suhirwan, \& Prakoso, L. Y. (2019a). Defense strategy at sea handling of Transnational Organized Crime (TNOC) in Nunukan Indonesia's national sea border. IOP Conference Series: Earth and Environmental Science, 339, 12043. https://doi.org/10.1088/17551315/339/1/012043 